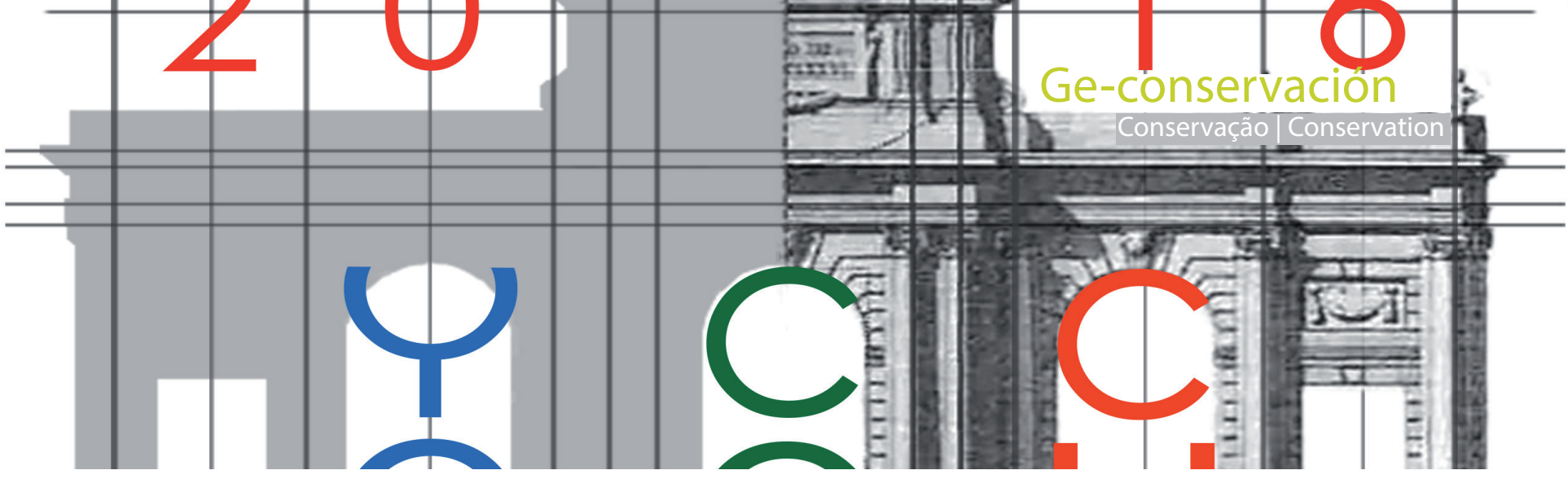

\title{
A wider study of contemporary art based on Mikel Diez Alaba's Mínimos series
}

\author{
Irene Cárdaba-López, Iraia Anthonisen-Añabeitia
}

\begin{abstract}
This research is based on the work of the Basque contemporary artist Mikel Diez Alaba and his series called Mínimos, which gathers up to 144 small size pieces made out of acrylic paint applied on printed images. This collection was displayed on the Museum of Fine Arts of Bilbao during 2014.

The main objective of this paper is to reach a more integral conception of conservation -based on the latest theories regarding heritage-, focusing on material aspects and the conceptual characteristics of the artwork, alike. Thereby, the working method in Mínimos series has been analyzed, as well as the presence of elements linked to the natural heritage. All this, taken together allows the establishment of new strategies towards the conservation of contemporary artworks.
\end{abstract}

Key words: Conservation, contemporary art, cultural heritage, natural heritage, landscape.

\section{Estudio integral de la obra contemporánea, el caso de la serie Mínimos de Mikel Diez Alaba}

Resumen: La presente investigación se basa en la obra del artista contemporáneo vasco Mikel Díez Alaba y su serie denominada Mínimos, que reúne hasta 144 pequeñas obras realizadas con pintura acrílica aplicada sobre imágenes impresas. Esta colección se expuso en el Museo de Bellas Artes de Bilbao durante el 2014.

El objetivo principal de este artículo es alcanzar una concepción integral de la conservación- basada en las últimas teorías sobre patrimonio-, que abarque tanto los aspectos materiales como conceptuales de las obras de arte. Para ello, se ha analizado la metodología de trabajo empleada en la serie de los Mínimos y la presencia implícita de los elementos relacionados con el patrimonio natural. Todo ello en su conjunto permite establecer nuevas estrategias para la conservación de obras de arte contemporáneas.

Palabras clave: Conservación, arte contemporáneo, patrimonio cultural, patrimonio natural, paisaje.

\section{Introduction}

When studying contemporary art it is necessary to establish an appropriate strategy to consider the work as a whole, with the aim of reinforcing its value. Therefore it is necessary to take into account current tendencies regarding the conservation of the heritage around the world. This paper reflects on the big change that the conception of the term heritage has withstood. From the ancient conception of "Historic-artistic heritage" which is strictly linked to the materiality of an artwork, to the new conception of "Cultural Heritage", opened to both tangible and intangible values.
Throughout his career, Mikel Diez Alaba -who is considered one of the main figures in the Basque scene of the 70s- has always been closely connected to its surroundings, what has to be taken into account when conserving these artworks, as it will be discussed in section Theoretical review about the artist.

This research is focused on the production of Diez Alaba during his latest period, named Mínimos due to their small size. To accomplish this study, the artistic evolution of Diez Alaba was studied to give an overview of his work and to understand the development of the artist's working method. Moreover, the artworks were analyzed both, 
for their materiality and their intangible value. Finally, several reflections were made in order to reach an integral conservation plan considering the authenticity value of these artworks.

\section{Several conservation concerns}

Paint as a way of breathing, let the paint spread itself driven by the feelings and let the hand sway with the breeze. Paint to contain the beauty, because painting is created in a breath and can be enjoyed many times, to put on record that we have existed and add some mark of our own to the universe (Diez Alaba 2016). This statement, from Diez Alaba, evidences that in his artworks not only is relevant the material procedure but also the value of some other immaterial aspects.

The aim in Mínimos is to present the essence of Minorcan landscape: showing the calm and peacefulness inherent of the natural heritage of the island. The conservation of these artistic documents is necessary to preserve different types of heritage: the artistic and the natural.

These ideas fit together with current tendencies regarding the conservation of heritage around the world. In fact it is important to point out the big change that the conception of the term "heritage" has withstood. During the first decades of the 20th century this concept was restricted to artifacts coming from past centuries, for instance antiquities with aesthetic values and exceptional nature. This conception evolved from the late twenties towards a wider theory where not only the artistic objects are considered but also cultural expressions, nature and intangible goods such as traditions and memories, are taking into account. (Querol 2010:458).

The new terminology corresponds to a new cultural moment in which the materiality is not enough and it is necessary to strengthen the conception of a wider catalog of cultural heritage. In fact, now, the idea of heritage should testify society's traditions, customs and believes in a specific historical context, these are tangible and intangible aspects.

The present work is based on the latest theories of European charters and agreements, that is "The Nara Document of Authenticity" (Lemaire and Stovel 1994) and the "European Landscape Convention" European Landscape Convention 2000). The former, refers to the intangible heritage and the authenticity that should be considered an essential part of our culture. According to the seventh article of the charter, all cultures and societies are rooted in the particular forms and means of tangible and intangible expression which constitute their heritage, and these should be respected.

As stated in the European Landscape Convention, it is necessary to be aware that the landscape contributes to the formation of local cultures and that it is a basic component of the European natural and cultural heritage, contributing to human well-being and consolidation of the European identity. For this reason and noting that developments in agriculture, forestry, industrial and mineral production techniques (...) are in many cases accelerating the transformation of landscapes, there is a need to preserve the testimony of them considering every dimension of their value: tangible and intangible.

Under the light of these considerations our aim is to highlight the co-existence of distinct goods regarding to the same heritage in Diez Alaba's latest works: the Minorcan landscape itself, the intangible values (feelings, sensations, ...) that are inherent to this space and the recording of such values in the Mínimos series. This way, we end up considering material and inmaterial goods as parts of the heritage that has to be conserved, also according to the most updated conservation criteria.

\section{Methods and methodology: study of the artworks}

In order to accomplish the main objective of this research, that is, to propose an integral conservation strategy, it is necessary to start giving an overview about the artist whose works are analyzed. After that, the research is focused on studying the concerning artworks, the Mínimos series. Finally, a detailed analysis of the paintings is described, evaluating their intangible value, up to the latest theories in conservation.

\section{-Theoretical review about the artist}

The artworks of Diez Alaba were studied from the very beginnings in order to give an overview of his work and to understand the development of his working method. The study is specially focused on the artist's latest period, which gathers the artworks done while living in Minorca (Balearic Island).

Table1.- Former vs new conception of the term heritage.

\begin{tabular}{lll}
\hline & FORMER CONCEPTION & NEW CONCEPTION \\
\hline VALUE & "Historic-artistic heritage" & "Cultural heritage" \\
& $\begin{array}{l}\text { Dependent on the time factor, artistic value, subjective } \\
\text { interpretation and uniqueness }\end{array}$ & Authenticity based on objective facts. \\
\hline WHAT GATHERS? & Exceptional productions generally linked to the power (Elitist) & $\begin{array}{l}\text { Cultural creations that testify society's traditions, customs } \\
\text { and beliefs (Generalist) }\end{array}$ \\
\hline WHAT & Material elements (tangible) & Material and inmaterial elements (intangible) \\
PROTECTS? & Produced by humans & Links nature and human trace (landscape) \\
\hline
\end{tabular}




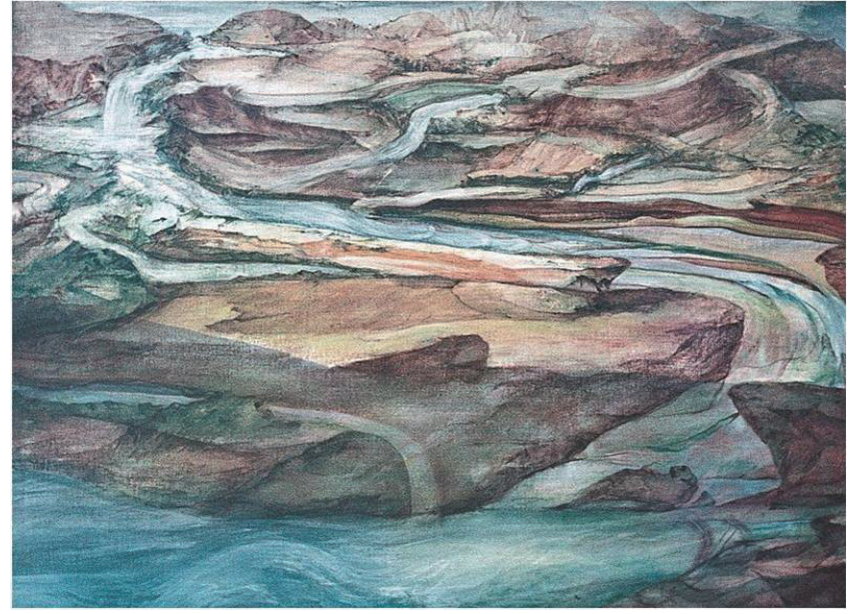

Figure1.- Mikel Diez Alaba Untitled, oil on canvas, (1981).

Diez Alaba was born in Bilbao in 1947 and his career has been marked by evolution; there can be highly distinguished two stages in his development as an artist.

The first phase went on until 1978. In this period he was influenced by British figurative painters such as, Francis Bacon and David Hockney, which favored the creation of expressionist works with an abstract tendency and critical sense.

The complicated socio-political situation that characterized this period caused him a great anguish and led him to quit painting for a year. Despair is absolute and I relieve it by painting. The need to paint didn't allow me to think. I gave free rein to impulse, thus the canvas gradually filled up with life or death with hardly any time spare for reflection (Diez Alaba 2016). This quotation reflects Diez Alaba's feelings and describes the characteristics of those works perfectly.

The second phase in his career followed immediately; he moved to the countryside and took time to rethink about his career and personal worries. At the beginning of this new stage, he paints based on the influence of Chinese paintings and the working method of the old masters, while trying to reach the origin of the painting techniques [figure 1]. Focused on the nature, the landscape turns, from now on, to be the main character in his works.

In 1981 he moved to Alaior (Minorca), where his work gradually took on Mediterranean values, such as luminosity, sensuality, etc. interested in the power of evocation and suggestion of the landscape, which brought to him the strong impression of the light and colour of the Mediterranean, as stated by the artist in several interviews.

In the first paintings of this new period, everything seems to be in apparent disorder, where the natural elements are mixed "chaotically". Black is gone and colors are purer; as the artist indicated Little by little, the space opens up, emptying, and at the same time the expression will be painted in a bid to recompose his own world. Thereafter, the artist followed a more sensitive and harmonious tendency in which the most important fact is the process of self-enrichment.

At this point, Diez Alaba is focused on the process of both, the material aspects of the artwork and the relation with the surrounding that inspired the creation. On his landscapes, he recreates calm and peaceful spatial environments with luminous tones, inherent to the natural heritage of the island.

According to him, the value is the process; the work is the consequence of it: I try to discover an approach through painting. Other conclusions are drawn after the work is finished. Intuition is fundamental and then reflection. You have to live with the forces of the universe for what you have to reconcile with living things, to take on movements and rhythms of nature (Salaberri and Sáenz de Gorbea 2001).

\section{—Study of the working methodology in Mínimos series}

Several reflections were derived from the previous theoretical research and from the interview with the artist. Diez Alaba's working method has changed over the years influenced by his surroundings; from realism and expressionism to abstraction- the works from the 80's onwards-, from big formats to small ones, and from the social and political situation at the beginning of his career to the scenery and peacefulness, showing the closeness with his feelings more than ever.

In Mínimos series he paints abstract interpretations of Minorcan landscape through the artists' eyes; sometimes appears the Mediterranean quietness but other shows its wildness.

This series look like fast sketches made during his trips around the island because of their small size- the artworks are about $6 \times 9 \mathrm{~cm}-$, but he produced them after reflecting about his feelings in those moments.

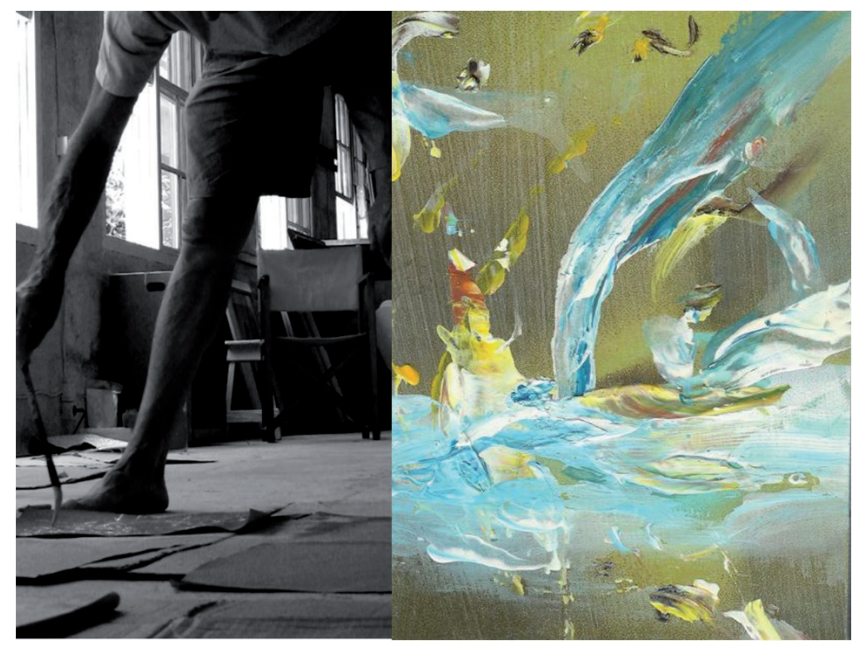

Figure 2.- Diez applying PVA on the substrates (left). A detail of the impastos in a Minimo (right). 
As in his first landscapes based on old masters, he prepares carefully the substrates before painting. First, he manipulates the images he took during his outings using Photoshop: he removes the color almost completely and makes some other distortions on them. Then he prints the images on office paper and applies several layers of PVA in order to protect the inkjet pigment inks. When the adhesive dries, he paints acrylic impastos with precise brush-strokes helped by special Japanese brushes. [figure 2]

Mikel Diez Alaba evokes the landscapes from memory, although he uses printed images in the way that he has an image to start [figure 3], he paints inspired from the recall he has of the surrounding scenery. For that he uses a short colour palette, mainly based on blue, white, green, red and yellow, which are the colours directly related to the nature -sky, water, clouds, vegetation, sun- and their reflection on different surfaces. [figure 4]

\section{—New insight into the analyses of the Mínimos series}

The study of Diez Alaba's Mínimos was guided by the aforementioned principles, which drew the investigation to analyze the artworks on their whole: considering both

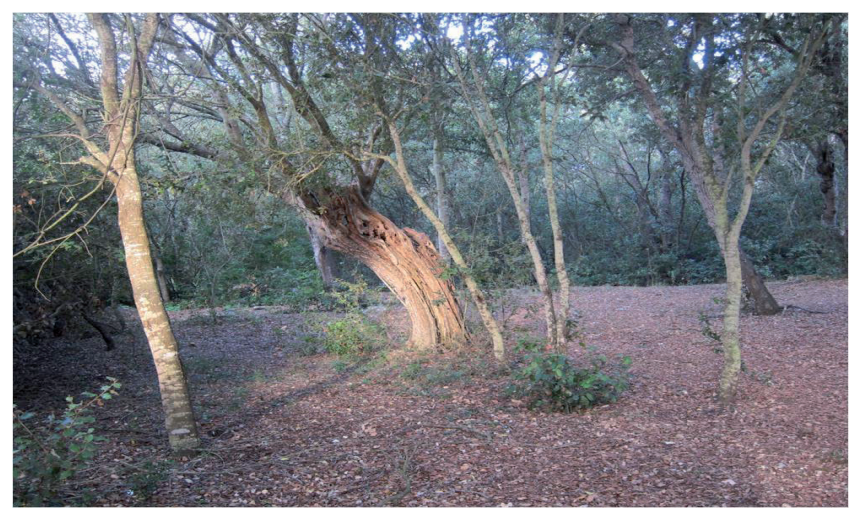

Figure 3.- Photography of the landscape taken by the artist.

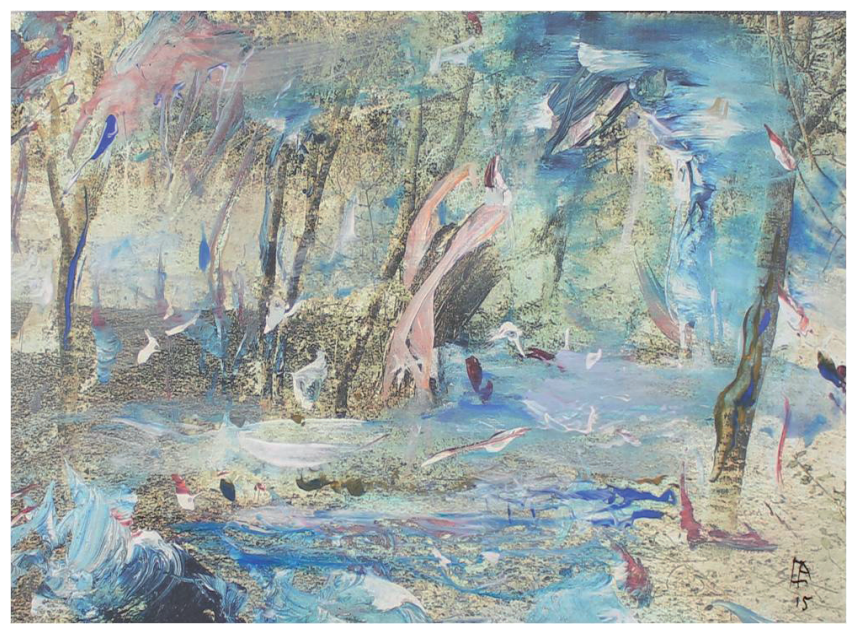

Figure 4.- Mikel Diez Alaba, title unknown, acrylic paint on printed image (2015). the tangible heritage (the paintings) and the intangible one together at the same time. The connection between the artwork and the landscape is represented in the relation between the colour palette, the environment and the sensations collected by the artist during his journeys across the island, which are depicted in particular traces. Moreover, his paintings gather aspects of society's collective memory (intangible heritage), since they evoke the constructed ideas about the main characteristics of the island: calm, peacefulness, etc. Thus, according to the proposal approached in these lines, it is compulsory to be aware of the following: if those intangible aspects are not considered, the Mínimos series would be altered or damaged in some way, so the conservation strategy would be inappropriate.

In order to accomplish an appropriate integral conservation strategy, in this case, we should consider three distinct levels and stages on the artist's working method, every one of each draws its own value. It is necessary to preserve every agent that takes part on the complex production of his work:

1. Specific landscape. This is the natural scenery itself which experiences changes due to the pass of time and the human activity. These modifications of the landscape are regulated by the standards of UNESCO, in order to maintain the quality of life and the environmental characteristics of the island. It is compulsory to take into account the natural value of the landscapes which are protected by law and are the main subjects of the cultural heritage of the island.

In fact, Minorca is recognized as a natural biosphere reserve by the UNESCO organization, due to its rich and traditional rural countryside and the high compatibility achieved by the island between the development of economic activities and landscape conservation.

Minorca is a member of the Spanish Network of Biosphere Reserves and it is also object of the sustainability program developed by the Consell Insular of the island. The latter, was established in order to maintain the quality of life in this territory and the environmental standards which merited the declaration of UNESCO. Among them, to avoid any measure or intervention which pose a threat to the landscape of Minorca.

2. Photography of a specific landscape. It is the natural scenery captured in a specific moment. There is a need to conserve these images as to preserve both, the registration of the evolutionary landscape and the Diez Alaba's artistic view. In several cases, they are the proof of a frozen instant of the aforementioned nature. They are testimony of a concrete moment in a specific place of the landscape which will probably suffer uncountable changes as time goes by.

3. Artist's view of the landscape. The artwork represents a specific landscape (stage 1) through the memory of 
the artist. It is necessary to preserve the artwork for its materiality but also for its immaterial values that represent the island. This corresponds to the highest level of abstraction both relating to the nature and the image. That is, on the one hand the conversion of the landscape into a memory inside the artist's mind. This could be considered an intangible good, part of the common imaginary.

On the other hand, there is a transfer of this memory into the work of art, through the use of painting materials. Here, the artist takes from the memory of these landscapes, the key elements that evoke its main values: quietness, peacefulness, and even the wildness in some cases through the use of colours and abstract traces applied over the prints.

Despite the triple classification, it is no possible to have one without the other. This means, that to tackle the conservation of Mínimos series it is necessary to afford its comprehension from a wider point of view.

\section{Conclusions}

As the landscape and surroundings are protected by the autonomous community's regulations, Diez Alaba's Mínimos also deserve special attention. Not only given the fact of being an artistic production but also for being provided by the value of the social identity, which belongs to the heritage of the island. Moreover, the correlation between the materiality and the conceptual baggage associated to the landscape, characterize the authenticity of the artworks, as stated in Nara's document. Therefore, it is safe to say that if we conserve the Mínimos series we are not only preserving their materiality but also the main natural good of a region, such as characteristics of a collective memory.

Taken together all the points detailed above, some general considerations are summarized:

- The need to establish an appropriate strategy for studying the works in their totality, so as to reach an integral conservation plan. Therefore, to study Diez Alaba's Mínimos in their totality, it is important to understand their close relation with the Minorcan landscape (protected by law) but also the thoughts and personal condition of the artist, which are part of the inherent intangible values. Without them, the artworks fall into decay.

- The previous study of Mínimos may reinforce their value, according to the present theories in the heritage scope.

- The importance of breaking walls while trying to manage a more integral conception of the conservation of our heritage. Consequently, the importance of the implicit intangible values will provide a more integral conception of the conservation of our heritage, and as a consequence, a more accurate preservation proposal, exceeding the materiality of the object.

These proposals are the basis for every research regarding contemporary art, where the study of the ideas (through personal interviews with the artist, deep study about its production, multidisciplinary approach to the heritage, etc.) is vital for conserving the materiality of the artifacts. After all, we could end up highlighting that the proposal of a more integral conservation plan of an artwork, in which various agents are taking part, (the tangible and the intangible ones) all of them deserve the same degree of consideration. Thus, helping and raising the value of the artworks.

For this reason, this paper is the beginning of the research about Mínimos series, as a starting point for further essays that ensure the conservation of the artworks.

\section{Aknowledgments}

We would like to thank Mikel Diez Alaba for his availability and help during the process of this research. The interviews and talks with him provided us wide information not only about his working methods but also about his thoughts.

\section{Bibliography}

ANTHONISEN-AÑABEITIA, l. et CARDABA-LOPEZ, I. (in press) "A wider study of contemporary art based on Mikel Diez Alaba's Mínimos series". In: 5th International Conference Youth in Conservation of Cultural Heritage YOCOCU 2016 Congress Book. Madrid: MNCARS.

DIEZ ALABA, M. http://www.mikeldiezalaba.com/ [accessed: 1602-2016].

European Landscape Convention (2000). Florence. http://gov. uk/government/publications/european-landscape-conventionflorence-20-october-2000 [accessed: 03.07.2017].

LEMAIRE, R; STOVEL, H. (1994) The Nara document on authenticity, http://icomos.org/charters/nara-e.pdf [accessed: 03.07.2017]

MARTINEZ PASCUAL, C; DIEZ INTXAUSTEGI, K. (2014) Mikel Díez Alaba: transitando un tiempo. Bilbao.

QUEROL, M.A.. (2010) Manual de gestión del patrimonio cultural, Akal, Madrid.

SALABERRI, P.; SAENZ DE GORBEA, X. (2001) Mikel Díez Alaba: del exterior al interior 1971-2001, Bilbao. 


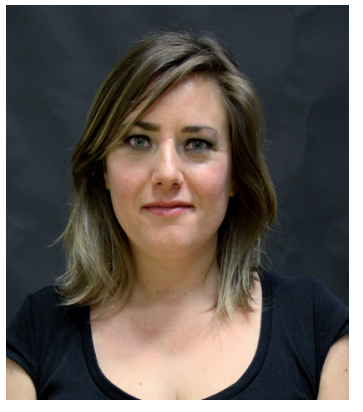

\section{Iraia Anthonisen Añabeitia}

Iraia.anthonisen@ehu.eus

Iraia Anthonisen Añabeitia: Graduated in Conservation and Restoration of Cultural Heritage at the University of the Basque Country. Worked for several years in the management and conservation of XXth century art collections. Master's degree in Conservation and Exhibition of Contemporary Art (CYXAC) at the same university (2013). Currently PhD student on digital printing conservation.

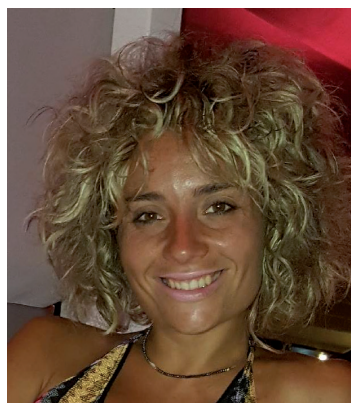

\section{Irene Cárdaba López}

Irene.cardaba@ehu.eus

Irene Cárdaba López: Graduated with Honours in Conservation and Restoration of Cultural Heritage at the University of the Basque Country (2014). Master's degree in Restoration, Rehabilitation and Integral Management of Built Heritage at the same University. Currently she is $\mathrm{PhD}$ student on contemporary paint. 